\title{
The Influence of Novice EFL/ESL Teacher’s Bilingual Identity on Self-Efficacy
}

\author{
Miri Yochanna \\ Kibbutzim College of Education, Tel Aviv, Israel
}

\begin{abstract}
Novice English as a foreign language (EFL) or second language (ESL) teachers' self-perception is highly affected by their belief of their language ability. This belief directly affects their self-efficacy as teachers, which in turn, has a negative effect on their teaching ability. This study explored the use of self-translation as a process that enables novice teachers to get a new sense of their language ability through bilingual experiences. Identifying oneself as bilingual has a positive influence on the teacher's self-perception, leading to a positive impact on their self-efficacy and confidence. Three groups of 30, third and fourth year EFL majors, experienced self-translation via narratives of personal experience during a one semester course and analyzed their language ability through these narratives. A mixed method approach was used for data collection. Quantitative data show a correlation between the participants' beliefs of bilingual teachers' abilities and their perception of their own teaching ability. Furthermore, a significant positive change was noticed in self-perception, bilingual identity, and self-efficacy. Qualitative data support this and indicate a higher comfort level as well as more confidence with language abilities after the self-translation experience, leading to a more positive self-perception of teaching ability and thus increasing self-efficacy.

Keyword: bilingual identity, ESL, teacher education, novice ESL teachers, self-translation, bilinguals
\end{abstract}

\section{Introduction}

English as a foreign language (EFL) or second language (ESL) teachers' self-perception of their language ability and their self-efficacy are strongly connected. Having a perception of a stronger and more solid language ability, enables more focus on teaching and less anxiety. If the novice teacher is worried about language knowledge or ability, anxiety will be high and teaching will be hindered (Yoon, 2012). This anxiety also affects self-efficacy leaving the novice teacher feeling unsure of their teaching ability.

However, if the EFL/ESL teacher were given the opportunity to learn more about his or her language ability and knowledge in both their languages and to develop a bilingual identity through positive bilingual experiences, there is a possibility that anxiety will lessen. One avenue that enables more self-awareness of language ability is self-translation. The bilingual self-translator translates their own work, using language knowledge in both the languages available, thus enabling more awareness of language ability.

Bilingual identity is a very individual aspect, which may influence the attitudes, feelings, and behavior of the person. Identifying oneself as bilingual requires a good understanding of what being bilingual means. Grosjean (2010) proposes a broad definition of bilingualism by saying that "Bilinguals are those who use two

Dr. Miri Yochanna, Ph.D., pedagogical instructor and lecturer, Faculty of Humanities and Social Sciences, English Department, Kibbutzim College of Education, Tel Aviv, Israel. 
or more languages (or dialects) in their everyday lives” (p. 4).

This definition may describe many, if not most, EFL or ESL teachers, although, as this study reveals, many novice ESL and EFL teachers would never consider themselves bilingual. This study makes use of self-translation as a tool to enable the novice teacher to discover their bilingual identity and help raise their self-efficacy.

\section{Teacher Self-Perception}

Teacher self-perception influences all aspects of a teacher's professional self. For ESL or EFL teachers, especially non-native English speakers, self-perception of their language ability is an additional facet of their self-perception and it has a major effect on their teaching. "Language proficiency constitutes the foundation of the professional confidence of non-native English teachers” (Ghasemboland \& Hashim, 2013, p. 891). According to Lange (1990 in Ghasemboland \& Hashim, 2013), competence in the language is seen "as the most essential characteristic of a good teacher” (p. 891). Shulman (1985 in Borg, 2001) noted that there was a direct relationship between "teachers' perceptions of their knowledge about grammar (KAG) and their instructional practices” (Borg, 2001, p. 21). Wilson and Shulman (1989 in Borg, 2001) reported that wherever teachers felt they lack in content knowledge, they taught differently and less confidently than when they taught something they perceived themselves to know well.

In research conducted by Reves and Medgyes (1994 in Hertel \& Gretchen, 2009) on non-native English speaker ESL instructors, it was found that "more than two-thirds believed that their own language difficulties affected their teaching” (p. 469). This finding reinforces the finding mentioned above, by Wilson and Shulman (1989 in Borg, 2001) stating the effect of ability on confidence.

Much research has shown that teachers' confidence in the classroom is empowered by their belief in their own ability. If the teachers perceive themselves as less able in language production or knowledge, their confidence in the classroom will be undermined and their teaching abilities will be affected greatly (Doff, 1987 in Ghasemboland \& Hashim, 2013).

\section{Teacher Efficacy}

"Self-efficacy is a motivational construct based on self-perception of competence rather than actual level of competence” (Ghasemboland \& Hashim, 2013, p. 891). "Teacher self-efficacy can influence teachers to be effective” (Dibapile, 2012, p. 81). Self-efficacy influences the teacher's ability to teach effectively in the classroom based on how the teacher views himself or herself. Bandura (1977) discusses outcome expectancy versus efficacy expectancy. "An outcome expectancy is defined as a person's estimate that a given behaviour will lead to certain outcomes. An efficacy expectation is the conviction that one can successfully execute the behaviour required to produce the outcomes" (p. 193). People with high self-efficacy in their abilities approach challenges with confidence. In contrast, people with low self-efficacy tend to dwell on their inabilities and give up quickly or don't put much effort into what they are doing as they feel it's useless to try (Bandura, 1994).

In a study conducted by Ghasemboland and Hashim (2013) on novice EFL teachers, it was found that "the teachers who rated their English proficiency higher in the four skill domains, tended to believe more strongly in their capability for teaching English” (p. 897). Furthermore, the teachers' self-efficacy beliefs were closely connected to the teachers' beliefs that they can carry out teaching task effectively. "Those who perceived they had sufficient English language proficiency tended to believe in their capability to carry out tasks related to 
student engagement” (p. 898) although they didn't feel as strongly about their ability in classroom management and instructional strategy. This study corroborates earlier studies cited by the researchers, Chacon (2002; 2005 in Ghasemboland \& Hashim, 2013), Lee (2009 in Ghasemboland \& Hashim, 2013), and Shim (2003 in Ghasemboland \& Hashim, 2013) in which “a significant association between English language proficiency and teacher efficacy” (p. 898) was documented.

The positive viewpoint of self-efficacy and self-perception is that teachers who perceive themselves in a negative manner can change towards a more positive view through guidance and training (Dibapile, 2012).

\section{Bilingualism and Bilingual Identity}

In recent years, the definition of bilingualism, or multilingualism, has changed to be more encompassing. Grosjean (2008) defines bilingualism as "the regular use of two or more languages (or dialects) and bilinguals are those people who use two or more languages (or dialects) in their everyday lives” (p. 10). Stavans and Hoffman (2015) define multilingualism as "a situation where a person has competence in more than one language, can use each of his or her languages in appropriate contexts and is able to alternate between languages” (p. 269). Using these definitions as descriptors, it might be expected that non-native English-speaking ESL/EFL teachers should perceive themselves as bilingual. However, this isn't the case.

The abundance of unsubstantiated beliefs around bilingualism has led to false understanding of what bilingualism is, which in turn caused many people to not consider themselves bilingual, even if they are, and believing that they will never be able to become bilingual. The most common myth is that to be considered a real bilingual, one must have equal abilities and equal fluency in both languages (Grosjean, 2008). This phenomenon of a "balanced" bilingual is rare, and it is natural for one language to be a dominant language, or for there to be dominance in some domains in one of the languages and in other domains in the other language. This may vary with time and circumstance for each individual (Ellis, 2016; Pearson, 2007). Although research has shown that being balanced is a rare phenomenon, many people still believe it to be true. When evaluating their own ability to this standard, they find they fall short and as a result don't consider themselves bilingual or not "really" bilingual. ESL/EFL non-native English teachers are no exception. Grosjean (2008) presents examples of bilinguals' evaluation of themselves who describe themselves as non-bilinguals—even though they are-by saying, "Yes, I use English every day at work, but I speak it so badly that I'm not really bilingual” (p. 13). This standard of evaluating who is a bilingual is very common and Grosjean says "it is time that we accept the fact that bilinguals are not two monolinguals in one person, but different, perfectly competent speaker-hearers in their own right” (p. 13).

Perceiving oneself as bilingual and able to use the other language freely creates an identity that raises oneself to a different level. Norton (2013) refers to this as "power". This is a power that enables access to privilege and future possibilities (West, 1992 in Norton, 2013). Furthermore, Weedon (1997 in Norton, 2013) says, "Language is the place where actual and possible forms of social organization and their likely social and political consequences are defined and contested. Yet it is also the place where our sense of ourselves, our subjectivity, is constructed” (p. 48). With bilingual identity comes power and many possibilities.

\section{Self-Translation}

Self-translation is not highly discussed in the world of translation. Cordingley (2013) defines the self-translator as "is a particular kind of cross-cultural interlocutor" (p. 1) who writes in at least two languages, 
crossing at least two cultures and for two different readers, usually in the world of literature. The self-translators translate their own writing, using the two languages at their disposal, and retelling or recreating the original text in a different language. This requires the self-translators be bilingual and confident in their language ability and knowledge.

"Self-translation demonstrates the difficulty of locating and articulating the self, since two languages collide one with another" (Todorov, 1985 in Klimkiewicz, 2013). This collision leads to enhanced engagement with the language which is required to enable expression at a level that the self-translator regards as appropriate. The ability to express one's self in two languages allows for a dynamic with language ability, with the process of creating meaning across languages, as well as greater awareness of strengths and weaknesses in both languages (Klimkiewicz, 2013). Self-translation requires in-depth reach of both the bilingual's languages, enabling an opportunity for change if needed.

According to Bandura (1994), the use of social cognitive theory, which is based on mastery experiences for change, could lead to change in self-efficacy in teachers. "The most effective way of creating a strong sense of efficacy is through mastery experiences” (p. 2). "Guided mastery is a powerful vehicle for instilling a robust sense of coping efficacy” (p. 6) in people who fear they aren’t capable of doing what is required of them. Mastery experiences are designed in such a way that they enable the subject to experience success no matter what. This leads to more self-efficacy and self-assurance. Successful experiences of self-translation would be regarded as a form of mastery experience, and can be utilized as a step towards improving the teacher's self-perception of language ability and as a result, self-efficacy.

Using self-translation as an aide for increased self-perception of language ability and teacher self-efficacy has not been studied, to the best of my knowledge, to date.

\section{Materials and Methods}

\section{Research Questions}

The research questions this study intends to answer are: (1) Can positive experiences of self-translation enhance self-perception and bilingual identity? (2) To what extend does an enhanced bilingual identity through successful self-translation affect self-efficacy in novice EFL/ESL teachers?

\section{Participants}

The participants in this study were approximately 40, third and fourth year students in the English Department in the Faculty of Humanities and Social Sciences at Kibbutzim College of Education, each year the study was run (2016, 2017, 2018). They were all novice teachers in their induction year and taught all grade levels. Likewise, they were all students in the course, "Bilingualism and Translation: A Living Connection". The course deals with bilingualism and leads the students through a step by step experience of self-translation via narratives of personal experience and understanding of their language abilities and their own bilingualism. Each participant experienced at least three self-translation exercises, each on different topics and with different analyses to allow for a broader view of their own language abilities.

\section{Data Collection}

A mixed method approach was used for data collection. Quantitative analysis was done based on anonymous pre and post questionnaires administered to the participants (See Appendix A). The questionnaires were distributed prior to beginning the course and at the last meeting. The questionnaires included 24 
statements that were divided into four sub-categories: bilingualism and what they believe bilingualism is (included Items 1-4, 9); self-perception of language ability and bilingualism (Items 5-8); bilingualism and teaching (Items 11-15): self-efficacy and bilingual teachers (Items 16-24). The participants were asked to rank each statement using the five-point Likert scale—strongly agree (5), agree (4), neutral (3), disagree (2), strongly disagree (1). These questionnaires were analysed for correlations and for significant differences using T-Tests.

Furthermore, these questionnaires included two open-ended questions relating to being bilingual and an ESL teacher. The first question appeared both in the pre and post questionnaires. The participants were asked to complete the following statement: "As an ESL teacher, if I were bilingual I would be able to..." (See Appendix A). The second question, which appeared only in the post questionnaire, was a reflective question, having the participants discuss any insights they gathered during the process: "After having experienced the self-translation process and learning about bilingualism, what insight do you have about your language ability and do you think it might have some effect on you as an ESL teacher?” (See Appendix B). Both questions were analysed using grounded theory procedures (Glaser \& Strauss, 1967).

\section{Results and Discussion}

The results from this study are divided into two parts: quantitative results and qualitative results. These results relate to all three groups in all three years of the study. Significant findings and differences are discussed.

\section{Quantitative Results}

The questionnaire included 24 statements, divided into four sub-categories. Each category was analysed separately.

Bilingualism and what they believe bilingualism is-Items 1-4, 9. The means in all three years of the study were very similar (2016: $\mathrm{M}=2.66$ vs. $2.10 ; 2017: \mathrm{M}=2.88$ vs. $2.06 ; 2018: \mathrm{M}=2.75$ vs. 2.38 ) and a drop in the means is seen for the three groups. This can be seen in Figure 1 below.

Figure 1: Items 1-4 and 9 - Bilingualism and their belief in what bilingualism is

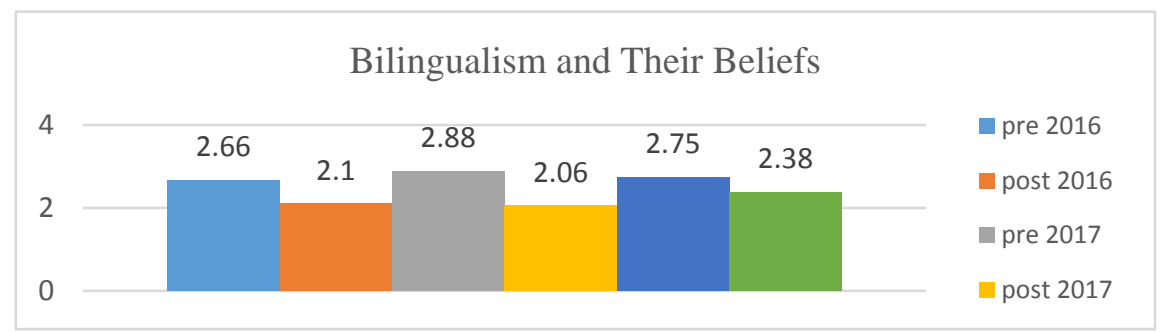

T-Tests were conducted on all the items in this section for pre and post questionnaires. The tests yielded significant differences for Item 2 which stated, "As an adult, one cannot become bilingual”, for all three years of the study (see Table 1). 
Table 1

Item 2-Pre and Post Questionnaires; All Three Years of Study

\begin{tabular}{llllll}
\hline Pair & & Mean & SD & t(df) & Sig. \\
\hline Item 2-2016 & Pre & 2.34 & 1.21 & $2.74(37)$ & 0.010 \\
& Post & 1.79 & 0.91 & $2.81(37)$ & \multirow{2}{*}{0.008} \\
\hline Item 2-2017 & Pre & 2.39 & 1.08 & $2.13(32)$ & \multirow{2}{*}{0.041} \\
& Post & 1.79 & 0.78 & 1.14 & \\
\hline Item 2-2018 & Pre & 2.63 & 0.80 & \\
& Post & 2.15 & & \\
\hline
\end{tabular}

These results indicate a shift towards a better understanding by the participants of what it means to be a bilingual, as expected. The other items, all dealing with similar issues, yielded less significant findings or only yielded significant findings in part of the studies (for example, 2016-Item 4 Pre vs. Post- $\mathrm{M}=2.95$ vs. $\mathrm{M}=$ 2.29, $\mathrm{p}=0.01$ ).

Self-perception of language ability and bilingualism-Items 5-8. In this sub-category, the means were similar in all three years of the study (2016: $\mathrm{M}=3.27$ vs. $3.34 ; 2017: \mathrm{M}=3.18$ vs. $3.46 ; 2018$ : $\mathrm{M}=3.20$ vs. 3.45). T-Tests were conducted; however, no significant differences were noted. What was seen was an increase in the means of Item 5, which stated, "I am bilingual”, in all three years (Pre vs. Post: 2016: M = 3.26 vs. 4.10; 2017: $\mathrm{M}=3.55$ vs. $4.11 ; 2018: \mathrm{M}=3.60$ vs. 4.12 ). The understanding that they could consider themselves bilingual is clearly noticed by this increase in value.

Bilingualism and teaching - Items 11-15. T-Tests and correlations were conducted on these items. The means showed slight change between the pre and post questionnaires (2016: $\mathrm{M}=3.26$ vs. 3.08; 2017: $\mathrm{M}=3.15$ vs. 3.22; 2018: $M=2.96$ vs. 3.00), yielding no significant differences and insignificant correlations. These findings indicate that no change took place in the participants' beliefs regarding bilingualism and teaching, although the qualitative results suggest otherwise. See Qualitative Results below.

Self-efficacy and bilingual teachers-Items 16-24. T-Tests and correlations were conducted on these items. The means showed very slight and insignificant change between the pre and post questionnaires (2016: $M=3.69$ vs. 3.53 ; 2017 : $M=3.68$ vs. $3.75 ; 2018$ : $M=3.45$ vs. 3.36 ). However, correlations were found between a number of the items. Item 24, "As a Hebrew-English bilingual ESL teacher, I can provide a clearer explanation of the English language than a non-native speaker" and Item 19, "If I could become bilingual, it would give me more confidence in the ESL classroom" yielded a strong correlation in the 2017 study $(\mathrm{r}=0.645$, $\mathrm{p}=0.000$ ) showing a direct connection between being bilingual and their confidence in the classroom. Likewise, Item 24 (above) and Item 20, "If I were bilingual, I would be able to teach ESL in all grade levels" yielded a strong correlation in the 2017 study $(r=0.568, p=0.000)$, again indicting a direct link between being bilingual and their confidence and teaching ability, i.e., their self-efficacy as teachers. A similar correlation was found in the 2016 study between Item 20 (above) and Item 18, "If I were to improve my English language ability, I would be a better ESL teacher" ( $\mathrm{r}=0.462, \mathrm{p}=0.008)$ and between Item 16, "If I were bilingual, I would be a better ESL teacher than I am today" and Item 18 (above) in the 2018 study ( $r=0.478, p=0.005)$. These findings indicate a connection between their perception of themselves as bilinguals and their teaching ability.

Conclusions. The quantitative results present a slight change in comprehension and indicate that the participants understood what it means to be bilingual. Many were able to perceive themselves as bilinguals if 
they hadn't prior to the course. The results also indicate a connection to the participants' beliefs that bilingual ESL teachers are better.

While the quantitative results seem minor, the qualitative results present a different viewpoint.

\section{Qualitative Results: Part Two of the Questionnaire}

The questionnaires required the participants to relate to two open ended questions, one in the pre (Part Two of the questionnaire-See Appendix A) and two in the post questionnaire (Part Three-See Appendix B). The results were analysed using grounded theory procedures and several categories arose from the analyses.

In Part Two of the questionnaire, the open-ended question in both the pre- and post-questionnaire, the participants were asked to complete the statement-As an ESL teacher, if I were bilingual, I would be able to... A few participants ( $\mathrm{N}=6$ for all three years in the pre but $\mathrm{N}=14$ in the post) changed the statement to "As an ESL teacher, since I am bilingual, I am able to...”. The analyses yielded two main categories: statements that dealt with confidence and statements that dealt with teaching ability. These were each then subdivided into two categories. The statements on confidence were divided into confidence in their language use in general and confidence in their teaching. The statements that dealt with teaching ability were likewise divided into two subcategories—-knowledge about the language they are teaching, i.e., English and their ability to better explain things in class.

Each category will be discussed separately.

Confidence. The first of the two categories is confidence. This category is divided into two subcategories, one dealing with confidence in general language use and one with teaching confidence.

Confidence in language use. In the pre-questionnaire, the participants in all three years of the study completed the statement "If I were bilingual I would ... with 'have more confidence', 'be more fluent', 'express myself better' as well as 'move more freely between languages'”.

In the post-questionnaire, similar statements were provided: "have more confidence", "be more fluent", "express myself better", and "feel more comfortable to speak spontaneously". However, an additional statement that indicates a shift in the participants' views of what it means to be bilingual was noted in all three years of the study; they wrote: "write with no spelling mistakes".

These results indicate that what was believed to be true about their abilities if they were bilingual expanded to include an additional skill, spelling, not discussed at the beginning of the process.

Confidence in teaching ability. Confidence in language ability was accompanied by confidence in their teaching ability. Their responses in the pre-questionnaire included "write on the board with no mistakes" reflecting the spelling ability discussed above, "teach with more confidence", "teach better", as well as a perception that being bilingual would enable them to "teach higher or more advanced levels". These responses indicate that, initially, there was a belief that bilingual language teachers have better abilities than non-bilingual language teachers.

However, in the post-questionnaire, a much broader range of abilities were attributed to their being bilingual teachers. Along with "teach at higher levels", the participants responded with "explain myself more clearly and give multiple examples", "use a wider range or a richer vocabulary", "strengthen my professional skills, knowledge of the language, output and understanding of the language system", "communicate fluently with my students", and "teach the material more confidently". These responses highlight a belief that being bilingual is accompanied by many abilities that are not necessarily part of the non-bilingual teacher's repertoire. 
An additional aspect that was seen in the post-questionnaire responses is their view on their rapport or relationship with their students. Responses dealt with a better connection with their students, "relate to my students on personal levels", as well as being a role model for their students, as in "I also believe my students look at my language ability skill and think they could one day be the same". This indicates the belief that being bilingual is something to strive for and an ability that is highly regarded.

Confidence in their language teaching ability was bolstered as a result of the self-translation experience. Having had an opportunity to interact on a personal level with their own language abilities, without judgement or evaluation, they discovered how adept they are in both their languages and their confidence improved. This was transferred from perception of their general language ability to their perception of their teaching ability.

Teaching ability. The second category is teaching ability. The participants' responses were diverse but could be divided into two main sub-categories, language knowledge and teaching ability and the ability to explain the material. Each sub-category will be discussed separately.

Language knowledge and teaching ability. Statements in this category included responses that connected teaching ability with language knowledge. In the pre-questionnaire, the participants completed the statement with "understand where the difficulties occur with the students' understanding and conceptions", "identify the source of many of the students' errors", "provide better English input for my students", "expose my students to authentic English", and even "have more teaching ideas and be more creative".

Similar responses were noted in the post-questionnaire, including "understand what my students are struggling with in the material", "have more knowledge and the potential to answer students' needs", and "identify problems stemming from their L1". However, after having undergone the process of self-translation, the responses indicate a clear connection to what they discovered about their own language abilities and how they are transferring this to their teaching ability. They stated that they would be able to "better understand students' thinking processes as well as their way of moving from one language to another", "understand the differences and similarities in the languages", as well as "help my students articulate difficult words easily because then I can direct them precisely how to use their oral organs as native Hebrew speakers".

Their responses show their belief that being bilingual enables them to have language abilities that include knowledge about the language as well as the ability to understand what their own students are experiencing.

Ability to explain and teaching ability. The second sub-category in teaching ability that was noted in Part 2 of the questionnaire, both in the pre and the post questionnaires, is the ability to explain. In the pre-questionnaire, the responses under this category included "point out where the two languages are similar or difference", "explain the different aspects of the languages taught to my students by comparing and contrasting", "give immediate answers to any question regarding the language (vocabulary, grammar, etc.)", "give clearer and more accurate information", and "find simpler words to explain complicated things in an easier way”.

In the post-questionnaire, similar responses were noted but they were more refined or worded differently. The participants stated that they would be able to "explain better to speakers of Hebrew", "give input in both languages where needed", "help my students understand how to think in English", "help my students understand their mistakes", "help them make connections more easily and identify and overcome difficulties", as well as "understand their confusion and help them" and "correct their mistakes better".

Moreover, their responses discussed an ability to go beyond explanation. They said they would be able to use their knowledge of the language "to the benefit of their students" as well as to be able to "reach everyone" 
in class. Their attitude towards their own bilingual ability shifted from simply knowing more about the language to an ability to teach more effectively on a variety of levels.

Conclusions. Part 2 of the questionnaire revealed a variety of beliefs that the participants had about being bilingual and its influence and effect on teaching ESL. The results indicate a change in their understanding of what being bilingual means as well as what they now feel able to do. The responses highlight their views that being a bilingual ESL/EFL teacher is beneficial to all involved, themselves and their students. They clearly describe attributes that could influence their teaching ability and their confidence in the classroom and in general language use. The self-translation experience bolstered their perception of what they are able to do simply by being bilingual.

\section{Qualitative Results: Part Three of the Questionnaire}

The post-questionnaire included a question that wasn't presented to the participants in the pre-questionnaire. It related to the self-translation experience and their studies on bilingualism. They were asked to reflect and discuss their insights on their language ability and whether they feel it had an effect on them as ESL teachers (See Appendix B).

The responses here divided into three main categories: insights on teaching, bilingual identity, and confidence. In the second and third years of the study, a fourth category appeared: self-translation. Each category will be discussed separately.

Insights on teaching. The participants discuss the change they experienced and how it has enabled them to look at their teaching differently. They mainly discuss the ability that they felt they've gained through the self-translation process, to better help their students with fluency and vocabulary use. This ability could lead to a stronger self-perception of their overall teaching ability and as a result improve self-efficacy.

It is important to note that the participants were not taught more language skills but were given an opportunity to utilize the knowledge they possessed.

Below are a few examples of their statements.

"I have a few insights but the biggest and more significant is that when I say things in both languages, I shouldn't expect to use the exact same words, but to convey the same message. I also make sure, in that case, that my students use both languages properly".

"Experiencing the self-translation process gave me the opportunity to understand better the issue of fluency which is something many English students are struggling with. I will be able to relate to my students better and help them become more fluent".

"I think that now I understand better that I can explain new words in different ways and find ways to express myself even if the word that I want to talk about doesn't exist in English".

"I think I am bilingual, and this gives me an advantage when it comes to explaining things. This allows me to have more insight on how I can assist my students and why they don't understand certain concepts in English. Overall, I think it is a great gift when it comes to teaching a foreign language".

Bilingual identity. The most significant shift noticed in Part 3 of the questionnaire is the change in the participants' view of themselves as bilinguals. Many of the participants identified themselves as bilinguals whereas they didn't do so prior to taking part in the course. Moreover, they felt their language abilities were now justified or acceptable as they could identify themselves as bilingual, and whatever idiosyncrasies they thought they had, could fall under "being bilingual". Examples of their statements are below. 
"More than anything, I now feel that my mistakes and little confusions are okay. I feel as though they are part of being a bilingual and instead of fearing the, I accept them".

"It helps the students feel more confident when they know even bilingual teachers make mistakes".

"Having experienced the self-translation process made me realize that I am, as a matter of fact, bilingual”.

"I hadn't realized I was bilingual. This realization enables me to feel more comfortable in the classroom. I have more confidence to answer language related questions in and out of the classroom".

"At the beginning I didn't think I was bilingual".

"I am bilingual".

Confidence. The participants' statements that fall under the category of confidence show that the newly acquired knowledge that they are, in fact, bilingual, and their experience through the self-translation process, has improved their confidence and has given them a different outlook on their abilities, both in regards to language ability and to teaching ability. This can be seen in the examples below.

"I feel much more confident regarding my English, as I am a bilingual, something that I didn't know before taking part in the course".

"I am more confident while speaking in front of my students".

"Naturally, I feel better and more confident to teach English. I consider myself now more knowledgeable in terms of the language".

"I definitely feel more confident with my abilities".

"The process gave me more confidence knowing I am bilingual, and this feeling helped me stand in front of my students or peers and believe I am more professional".

Self-Translation. In the second and third years of the study (2017 and 2018), the participants related to the self-translation experience directly and some even noted that the tool could be used in their own classes. The main point expressed was their discovery of their language abilities and the connection between their two languages. They stated that the experience helped them improve their language abilities and how they see themselves using the languages now. Some examples of statements appear below.

"My language abilities improved once I translated myself".

"My translation ability is better than I thought".

“The process made me aware that there isn't 100\% correspondence between the two languages which influences how we teach vocabulary".

"The exercises made me realize that I think completely differently in the two languages".

"Self-translation of narratives of personal experience can be used as a tool in class".

"It (self-translation) can help me teach authentic writing and speaking skills".

Conclusions. The self-translation process, alongside learning about bilingualism, had a mostly positive influence on the participants. One participant was a little less positive and noted that the self-translation process helped them notice that their "abilities in English are less than (they) expected". However, the rest of the responses and insights were positive and showed a shift if confidence, in bilingual identity and in their perception of their own teaching ability.

\section{Conclusions}

This research set out to discover whether a change in perception of bilingual identity and ability could 
change the self-efficacy of novice teachers. Self-efficacy among novice non-native English speaker ESL/EFL teachers is hindered by two elements - their novice status and their perception of their lack of language ability. Ghasemboland and Hashim (2013) state that self-efficacy has a strong influence on the teacher's effectiveness in the classroom. In their research they note that a stronger perception of English language proficiency also led to a more positive belief in teaching ability. Identifying oneself as bilingual has the potential to raise the level of self-perception and self-efficacy by the virtue of seeing oneself possessing language ability (Norton, 2013).

The participants in this study learned about bilingualism and went through a process of self-translation and reflection on language ability during the course. While the quantitative results show a shift towards a better understanding of what it means to be bilingual, the qualitative results present the change the participants went through in their perception of both their language abilities and their teaching abilities.

The results indicate that the use of self-translation as a tool to self-discovery of language ability was successful and led to improved self-efficacy of the novice ESL/EFL teachers. The experience with self-translation helped them identify themselves as bilingual. Their newly discovered bilingual identity enabled them to feel more confident in their language knowledge, their language ability, and their teaching ability. Their statements show the change that they experienced and how their perception of their abilities improved. A feeling of confidence in their language knowledge and ability, and identifying themselves as bilingual enabled the novice teachers to feel more confident as ESL/EFL teachers.

More confident teachers have a more positive self-efficacy. Stronger self-efficacy enables the teachers, especially the novice teachers, to focus on their teaching, which should lead to more effective and efficient teaching. Success in class will strengthen the novice teacher's self-perception and will lead to more confident teachers. Tools to help novice teachers improve their self-efficacy are essential to creating confident, successful, and happy teachers.

\section{References}

Bandura, A. (1977). Self-efficacy: Toward a unifying theory of behavioral change. Psychological Review, 84(2), 191-215.

Bandura, A. (1994). Self-efficacy. In V. S. Ramachaudran (Ed.), Encyclopedia of human behavior (Vol. 4, pp. 71-81). New York: Academic Press. (Reprinted in H. Friedman [Ed.], Encyclopedia of mental health. San Diego: Academic Press, 1998)

Borg, S. (2001). Self-perception and practice in teaching grammar. ELT Journal, 55(1), 21-29.

Cordingley, A. (2013). Introduction: Self-translation, going global. In A. Cordingley (Ed.), Self-translation: Brokering originality in hybrid culture (pp. 1-10). London and New York: Bloomsbury.

Dibapile, W. T. S. (2012). A review of literature on teacher efficacy and classroom management. Journal of College Teaching and Learning, 9(2), 79-92.

Ellis, E. (2016). The plurilingual TESOL teacher. The hidden languaged lives of TESOL teachers and why they matter. Berlin: De Gruyter Mouton

Ghasemboland, F., \& Hashim, F. B. (2013). Teachers' self-efficacy beliefs and their English language proficiency: A study of nonnative EFL teachers in selected language centers. Procedia-Social and Behavioral Sciences, 103, 890-899.

Glaser, B. G., \& Strauss, A. L. (1967). The discovery of grounded theory: Strategies for qualitative research. Chicago, IL: Aldine Publications.

Grosjean, F. (2008). Studying bilinguals. Oxford: Oxford University Press.

Grosjean, F. (2010). Bilingual; life and reality. Cambridge: Harvard University Press.

Hertel, T. J., \& Gretchen, S. (2009). Student attitudes toward native and non-native language instructors. Foreign Language Annals, 42(3), 468-482.

Klimkiewicz, A. (2013). Chapter twelve self-translation as broken narrativity: Towards an understanding of the self's multilingual dialogue. In A. Cordingley (Ed.), Self-translation: Brokering originality in hybrid culture (pp. 189-201). London and New York: Bloomsbury. 
Norton, B. (2013). Identity and language learning, extending the conversation (2nd ed.). Bristol: Multilingual Matters Press.

Pearson, B. Z. (2007). Children with two languages. In E. Bavin (Ed.), Handbook of child language (pp. 379-398). Cambridge: Cambridge U.P.

Stavans, A., \& Hoffman, C. (2015). Multilingualism. Cambridge: Cambridge University Press.

Yoon, T. (2012). Teaching English through English: Exploring anxiety in non-native pre-service ESL teachers. Theory and

Practice in Language Studies, 2(6), 1099-1107.

\section{Appendix A: Pre-Questionnaire}

Dear Participant,

Thank you for taking part in this research. It is greatly appreciated.

Please answer truthfully. This information is for research purposes only and won't be used in any other manner without your permission or knowledge.

Below you will find 24 statements (Part I) that deal with bilingualism and teaching ESL (English as a Second Language). Each one is followed by a five-point scale as your view regarding the statement. Please read each one carefully and mark whether you strongly agree (5), agree (4), are neutral towards it (3), disagree (2) or strongly disagree with it (1).

Following these statements, you will be asked to complete a statement in a few words (Part II). Please do so in clear handwriting and as truthfully for yourself as possible.

Finally you will be asked to fill in a few personal identification questions for my records (Part III). Again, no use will be made of this but it will provide me with an opportunity to approach you personally should the need arise and should you be willing.

Please make sure to fill in the entire questionnaire.

Thank you for your time and your help.

Sincerely,

February 27th, 2018

Part I: Please circle to what extent you agree or disagree with each statement.

\begin{tabular}{|c|c|c|c|c|c|c|}
\hline & Statements & $\begin{array}{l}\text { Strongly } \\
\text { Agree }\end{array}$ & Agree & Neutral & Disagree & $\begin{array}{l}\text { Strongly } \\
\text { Disagree }\end{array}$ \\
\hline 1. & In order to be bilingual you have to grow up speaking two languages. & 5 & 4 & 3 & 2 & 1 \\
\hline 2. & As an adult, one cannot become bilingual. & 5 & 4 & 3 & 2 & 1 \\
\hline 3. & Being bilingual means you are equally fluent in both languages. & 5 & 4 & 3 & 2 & 1 \\
\hline 4. & $\begin{array}{l}\text { Being bilingual means your language abilities in both languages are equal } \\
\text { to monolinguals of each language. }\end{array}$ & 5 & 4 & 3 & 2 & 1 \\
\hline 5. & I am bilingual. & 5 & 4 & 3 & 2 & 1 \\
\hline 6. & I feel more confident when I speak Hebrew. & 5 & 4 & 3 & 2 & 1 \\
\hline 7. & I feel more confident when I speak English. & 5 & 4 & 3 & 2 & 1 \\
\hline 8. & My language ability in English and Hebrew are nearly equal. & 5 & 4 & 3 & 2 & 1 \\
\hline 9. & Being bilingual means you have two native languages from birth. & 5 & 4 & 3 & 2 & 1 \\
\hline 10. & $\begin{array}{l}\text { I would rather learn English from someone who is a native English } \\
\text { speaker. }\end{array}$ & 5 & 4 & 3 & 2 & 1 \\
\hline 11. & $\begin{array}{l}\text { I would rather learn English from someone who is an English-Hebrew } \\
\text { bilingual. }\end{array}$ & 5 & 4 & 3 & 2 & 1 \\
\hline \multirow[t]{2}{*}{12.} & $\begin{array}{l}\text { ESL teachers who are native English speakers are better teachers than } \\
\text { those who are bilingual. }\end{array}$ & 5 & 4 & 3 & 2 & 1 \\
\hline & 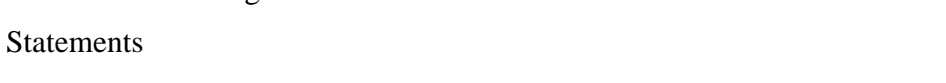 & $\begin{array}{l}\text { Strongly } \\
\text { Agree }\end{array}$ & Agree & Neutral & Disagree & $\begin{array}{l}\text { Strongly } \\
\text { Disagree }\end{array}$ \\
\hline 13. & $\begin{array}{l}\text { Being a native English speaker gives you an advantage over non-native } \\
\text { English speakers as an ESL teacher. }\end{array}$ & 5 & 4 & 3 & 2 & 1 \\
\hline
\end{tabular}


14. Bilingual ESL teachers have an advantage over others.

15. Bilingual ESL teachers are the best teachers.

\begin{tabular}{lllll}
5 & 4 & 3 & 2 & 1 \\
5 & 4 & 3 & 2 & 1 \\
5 & 4 & 3 & 2 & 1 \\
5 & 4 & 3 & 2 & 1 \\
5 & 4 & 3 & 2 & 1 \\
5 & 4 & 3 & 2 & 1 \\
5 & 4 & 3 & 2 & 1 \\
5 & 4 & 3 & 2 & 1 \\
5 & 4 & 3 & 2 & 1 \\
5 & 4 & 3 & 2 & 1 \\
5 & 4 & 3 & 2 & 1 \\
\hline
\end{tabular}

16. Being bilingual would make me a better ESL teacher than I am today.

17. I consider myself to be a very good ESL teacher.

18. If I were to improve my English language ability, I would be a better ESL teacher.

19. Being bilingual would give me more confidence in the ESL classroom.

20. Being bilingual would enable me to teach ESL in all grade levels.

21. Being bilingual would enable me to get a teaching job more easily.

22. Being a bilingual ESL teacher would enable me to better understand my student's needs.

23. As a Hebrew-English bilingual ESL teacher I can understand what the students are having problems with in English.

24. As a Hebrew-English bilingual ESL teacher I can provide a clearer explanation of the English language than a non-native speaker.

Part II: Please complete the sentence in a few words.

As an ESL teacher, being bilingual would enable me to

Part III: Personal Information (for the researcher's records only).

1. Full name:

2. Email:

3. Mobile phone number:

4. Mother tongue:

5. Other languages that you speak (list all):

6. Teaching this year: Yes/No. Grade levels if yes:

7. I hereby grant permission to the researcher to use the information in this questionnaire for her research.

\section{Appendix B: Post-Questionnaire}

Dear Participant,

Thank you for taking part in this research. It is greatly appreciated.

Please answer truthfully. This information is for research purposes only and won't be used in any other manner without your permission or knowledge.

Below you will find 24 statements (Part I) that deal with bilingualism and teaching ESL (English as a Second Language). Each one is followed by a five-point scale as your view regarding the statement. Please read each one carefully and mark whether you strongly agree (5), agree (4), are neutral towards it (3), disagree (2) or strongly disagree with it (1).

Following these statements, you will be asked to complete a statement in a few words (Part II). Please do so in clear handwriting and as truthfully for yourself as possible.

At the end, there is a question where I would appreciate your views on the process in the course. Please answer the question as best you can.

Finally you will be asked to fill in a few personal identification questions for my records (Part III). Again, no use will be made of this but it will provide me with an opportunity to approach you personally should the need arise and should you be willing. 
Please make sure to fill in the entire questionnaire.

Thank you for your time and your help.

Sincerely,

Part I: Please circle to what extent you agree or disagree with each statement.

\begin{tabular}{|c|c|c|c|c|c|c|}
\hline & Statements & $\begin{array}{l}\text { Strongly } \\
\text { Agree }\end{array}$ & Agree & Neutral & Disagree & $\begin{array}{l}\text { Strongly } \\
\text { Disagree }\end{array}$ \\
\hline 1. & In order to be bilingual you have to grow up speaking two languages. & 5 & 4 & 3 & 2 & 1 \\
\hline 2. & As an adult, one cannot become bilingual. & 5 & 4 & 3 & 2 & 1 \\
\hline 3. & Being bilingual means you are equally fluent in both languages. & 5 & 4 & 3 & 2 & 1 \\
\hline 4. & $\begin{array}{l}\text { Being bilingual means your language abilities in both languages are equal } \\
\text { to monolinguals of each language. }\end{array}$ & 5 & 4 & 3 & 2 & 1 \\
\hline 5. & I am bilingual. & 5 & 4 & 3 & 2 & 1 \\
\hline 6. & I feel more confident when I speak Hebrew. & 5 & 4 & 3 & 2 & 1 \\
\hline 7. & I feel more confident when I speak English. & 5 & 4 & 3 & 2 & 1 \\
\hline 8. & My language ability in English and Hebrew are nearly equal. & 5 & 4 & 3 & 2 & 1 \\
\hline 9. & Being bilingual means you have two native languages from birth. & 5 & 4 & 3 & 2 & 1 \\
\hline 10. & $\begin{array}{l}\text { I would rather learn English from someone who is a native English } \\
\text { speaker. }\end{array}$ & 5 & 4 & 3 & 2 & 1 \\
\hline 11. & $\begin{array}{l}\text { I would rather learn English from someone who is an English-Hebrew } \\
\text { bilingual. }\end{array}$ & 5 & 4 & 3 & 2 & 1 \\
\hline \multirow[t]{2}{*}{12.} & $\begin{array}{l}\text { ESL teachers who are native English speakers are better teachers than } \\
\text { those who are bilingual. }\end{array}$ & 5 & 4 & 3 & 2 & 1 \\
\hline & ( & $\begin{array}{l}\text { Strongly } \\
\text { Agree }\end{array}$ & Agree & Neutral & Disagree & $\begin{array}{l}\text { Strongly } \\
\text { Disagree }\end{array}$ \\
\hline 13. & $\begin{array}{l}\text { Being a native English speaker gives you an advantage over non-native } \\
\text { English speakers as an ESL teacher. }\end{array}$ & 5 & 4 & 3 & 2 & 1 \\
\hline 14. & Bilingual ESL teachers have an advantage over others. & 5 & 4 & 3 & 2 & 1 \\
\hline 15. & Bilingual ESL teachers are the best teachers. & 5 & 4 & 3 & 2 & 1 \\
\hline 16. & If I were bilingual, I would be a better ESL teacher than I am today. & 5 & 4 & 3 & 2 & 1 \\
\hline 17. & I consider myself to be a very good ESL teacher. & 5 & 4 & 3 & 2 & 1 \\
\hline 18. & $\begin{array}{l}\text { If I were to improve my English language ability, I would be a better ESL } \\
\text { teacher. }\end{array}$ & 5 & 4 & 3 & 2 & 1 \\
\hline 19. & $\begin{array}{l}\text { If I could become bilingual, it would give me more confidence in the ESL } \\
\text { classroom. }\end{array}$ & 5 & 4 & 3 & 2 & 1 \\
\hline 20. & If I were bilingual I would be able to teach ESL in all grade levels. & 5 & 4 & 3 & 2 & 1 \\
\hline 21. & If I were bilingual I would be able to get a teaching job more easily. & 5 & 4 & 3 & 2 & 1 \\
\hline 22. & $\begin{array}{l}\text { Being a bilingual ESL teacher would enable me to better understand my } \\
\text { student's needs. }\end{array}$ & 5 & 4 & 3 & 2 & 1 \\
\hline 23. & $\begin{array}{l}\text { As a Hebrew-English bilingual ESL teacher I can understand what the } \\
\text { students are having problems with in English. }\end{array}$ & 5 & 4 & 3 & 2 & 1 \\
\hline 24. & $\begin{array}{l}\text { As a Hebrew-English bilingual ESL teacher I can provide a clearer } \\
\text { explanation of the English language than a non-native speaker. }\end{array}$ & 5 & 4 & 3 & 2 & 1 \\
\hline
\end{tabular}

Part II: Please complete the sentence in a few words.

As an ESL teacher, if I were bilingual I would be able to 
Part III: Please answer the question in a short paragraph.

After having experienced the self-translation process and learning about bilingualism, what insight do you have about your language ability and do you think it might have some effect on you as an ESL teacher?

Part IV: Personal Information (for the researcher's records only).

1. Full name:

2. Email:

3. Mobile phone number:

4. Mother tongue:

5. Other languages that you speak (list all):

6. Teaching this year: Yes/No. Grade levels if yes:

7. I hereby grant permission to the researcher to use the information in this questionnaire for her research. 